\title{
Welfare From Below: Recipients' Views of the Public Welfare System ${ }^{\dagger}$
}

\author{
Scott Briar*
}

I think the Welfare Department is too soft, too lenient. They don't make investigations to see how the welfare money is being spent. If the workers went to the house more often they would be able to tell if people are cheating. They could go to the home anytime they want to, day or night. If the person isn't guilty, then they shouldn't care when the worker comes.

$\mathrm{T}$ HEESE ARE NOT THE WORDS of an irate taxpayer or public official concerned about the rising costs of public welfare programs. On the contrary, this statement was made by a poorly educated welfare recipient living in the Negro ghetto of an industrial city. But the importance of this statement is that these views are not atypical of the opinions expressed by the more than ninety welfare recipients interviewed in the study reported in this article.

In the growing body of literature on what has been called "the law of the poor," little attention has been paid to the conceptions held by the poor themselves about their relationship to the law and to legal and quasi-legal institutions. This omission is partly due to the lack of systematic data on this subject, a lack which is only beginning to be remedied..$^{2}$ Another explanation, one which partly accounts both for the inattention to the conceptions of law lield by the poor and for the lack of research on the subject, is found in two assumptions which appear in some of the recent literature ${ }^{3}$ on the law of the poor: (1) that one of the basic social problems in this area is the lack of legal services; and (2)

$\dagger$ This article is based on research supported by Grant No. 230 E-5-141, Welfare Administration, U.S. Department of Health, Education, and Welfare and in part by a grant from the California State Department of Social Welfare to the Social Welfare Research Projects Office, School of Social Welfare, University of California. The author acknowledges the assistance of Miss Mildred Alexander in the development of the interview schedule used in this research and the contribution of Mrs. Naomi Streshinsky to all stages of the work reported here.

* D.S.W., 1961, Columbia University; Associate Professor, School of Social Welfare, and Research Associate, Social Welfare Research Projects Office and Center for the Study of Law and Society, University of California, Berkeley.

I E.g., U.S. Dep't of Health, Educ. \& Welfare, The Extension of Legal Services To THE POOR (1964); Carlin \& Howard, Legal Representation and Class Justice, 12 U.C.I.A.L. REv. 381 (1965). (1965).

2 See, e.g., Zeitz, Survey of Negro Attitudes Toward Law, 19 RuTGers L. Rev, 288

3 See, e.g., The Extension of Legai Services to the Poor, op. cit. supra note 1, passim. 
that if legal services are provided, the poor will use them. The former assumption is well supported, but the validity of the second is in doubt.

While some programs designed to extend legal services to the poor have reported success, others have not, for reasons which appear to be due in part to the attitudes of potential users among the poor. An example is Sparer's description of the problems arising because of the sentiments and attitudes held by potential users of the Mobilization for Youth Legal Services Unit; for example, he notes that "they felt too unsure of themselves to argue with-or insist upon anything with [officials] . ..."

Thus one reason for conducting studies in this area is that knowledge about the views of law held by the poor may be useful in designing effective programs for extending legal services to them. Second, such research inay shed light on the effects of the legal order on the persons directly affected. The experiences of the poor may be particularly instructive in this regard since the poor are more likely than others to be directly affected by certain major legal institutions, particularly the police, the courts, and the correction agencies.

This article attempts to contribute to both of the above aims by describing the findings of a study concerned in part with welfare recipients' views of the welfare agency. It should be emphasized that welfare recipients constitute only a portion of the population living in poverty, ${ }^{5}$ and therefore the findings reported here cannot be generalized to the nonwelfare poor. The welfare poor tend to be more impoverished and to be afflicted by other problems to a greater extent than the nonwelfare poor. ${ }^{6}$ Most important, the welfare poor live dependent on the operations of an institution, the public welfare agency, established to administer welfare legislation.

\footnotetext{
4 Sparer, Education on New York's Lower East Side, in Tae Extension of Legat SERVICES, op. cit. supra note 1 , at 123 .

5 Estimates of the proportion of the poor who are welfare recipients vary, partly as a function of the definition of poverty. Morgan et al. estimate that twenty-three per cent of all poor families receive public assistance. Morgan, DAvD, CoHEN \& Brazer, INCOME AND WeLFARE IN THE UNTKED STATES 216 (1962).

${ }^{6}$ There have been few systematic studies of the differences between welfare and nonwelfare poor. Robert Stone, of the Institute of Social Science Research, San Francisco State College, in a study still in process, attempted to find a matching, nonwelfare sample for comparison to a sample of AFDC-U, CAL. WELFARE \& INST'NS CODE $\$ \S 11201,11250$, families. After much effort, he had to settle for a nonwelfare group which, although it was otherwise comparable, had a higher average income than the AFDC-U sample. Sydney Bernard found that the essential difference between welfare applicants and nonapplicants im a homogeneous low-income neighborhood was that the nonapplicants had more financial resources of various sorts available to them than the applicants. Bernard, The Economic and Social Adjustment of Low-Income Female-Headed Families, May, 1964 (unpublished, Florence Heller Graduate School for Advanced Studies in Social Welfare, Brandeis University).
} 


\section{THE STUDY}

The study reported here is part of a continuing project concerning the impact of public welfare policies and operations on family life. As part of the exploratory phase of this project, intensive interviews were conducted with more than one lundred recipients of AFDC-U ${ }^{7}$ (the program which provides aid to intact families with dependent children in which the father is unemployed). ${ }^{8}$ These interviews, which ranged in length from three to six loours extending over two to three sessions, probed systematically and in depth eacl recipient's experiences with the agency, his conceptions of the agency and its operations, his perceptions of his rigltts and obligations vis-à-vis the agency, his attitude towards certain welfare policies and issues, and the effects of recipient status on his family life. ${ }^{9}$

The findings presented in this article are based primarily on interviews conducted with a systematically selected sample of ninety-two AFDC-U recipients, consisting of forty-six married couples leading family units in recent receipt of AFDC-U funds. Since the lusbands and wives were interviewed separately (using the same interview schedule), and since the husband and wife in the same family frequently differed in their responses to questions about the agency and their separate experiences with it, the data are reported for individuals rather than families.10

The recipients were selected from the official rolls of the county welfare department in inverse order of date of application, beginning with the most recent applicant prior to July 1, 1965. A quota sampling procedure was used to yield an equal number of recipients in each of the three major ethnic groups in the county studied; thus the sample includes thirty Caucasian (fifteen families), thirty Negro (fifteen families), and

7 Cal. Wetfare \& INST'NS Code $\$ \$ 11201,11250$.

8 The author acknowledges the assistance of the following graduate students at the University of California, Berkeley, in conducting some of these interviews: Arlene Brasher, Archie Hanlan, Susan Reed, Hezekiah Singleton, and Arabella Springer.

$9 \mathrm{~A}$ structured schedule was used in these interviews to insure that comparable data were collected from the respondents. So far as possible, responses were pre-coded (on the basis of pre-test interviews). In addition, all interviews were tape recorded so that each recipient's free responses also would be available for analysis.

10 There are several reasons for treating the forty-six couples as ninety-two individual recipients in the presentation of findings. As noted in the text, the husband and wife in each family were interviewed separately, and their views of the recipient experience frequently differed (although the distribution of responses for husbands and wives as groups typically do not differ substantially) so that it is not possible to speak of a "family" response. The sample, however, is not and should not be construed as consisting of ninety-two independent recipients; rather it is a cohort of husbands and wives receiving AFDC-U. 
thirty-two Mexican-American (sixteen families) AFDC-U recipients. ${ }^{11}$ In many instances the distribution of responses obtained from these three groups are, in effect, identical; consequently, findings are reported for the total sample, except where significant or systematic differences among the three ethnic groups were found.

In a study of this sort the question of response validity always must be considered. Did the recipients report their "true" beliefs and opinions, or did they say what they thought the interviewers wanted to hear? Important as these questions are, they are difficult to answer categorically. Nevertheless, in this study there are a number of reasons for believing that the responses obtained reflect the recipients' own opinions. First, in approaching recipients, interviewers identified themselves as being with the University of California and took great pains to make clear that the study was not connected with the welfare department. Second, recipients frequently made comments about the welfare agency and their experiences with it that they would have been unlikely to make had they believed the agency would have access to their responses. Third, Negro recipients were interviewed by a Negro interviewer, and Spanish-speaking interviewers were used with the Mexican-American recipients. Fourth, the interviewers spent from three to seven hours (in more than one session) with eaclı respondent. Fifth, the dominant responses reported herein were contrary to what the interviewers privately had hoped and wanted to hear; the responses revealed a state of affairs which was a source of frustration to the interviewers and which made it necessary to caution the interviewers to check their desires to educate and inform the recipients about their "rights." Finally, the most convincing test of validity is the extent to which the responses obtained are consistent with other known beliefs and behaviors of the group studied; this aspect is considered following presentation of the findings.

The welfare department in the county in which this researcli was conducted has acquired a reputation both locally and nationally for its progressiveness. Thus the recipients interviewed in this study are somewhat atypical in that their welfare experiences have been with a department which is unusual in the degree of its commitment to a professional and client-oriented approach to welfare services. It is not known, however, to what extent or in what respect recipients' perceptions of the welfare

11 The actual proportions of these three groups in the AFDC-U population in the county studied, as of July 1964, were: Caucasian, 50.3\%; Mexican-American, 10.8\%; and Negro, 38.9\%. Californta State Dep't of Soctat Welfare, Researce and Statistics. Comparison of the study sample with known characteristics (for example, family size, age, education, and usual occupation of the unemployed parent) of the AFDC-U population in the community studied revealed no great differences between the two groups. 
system vary in relation to the character of the welfare department-these questions require further research.

It should be noted that the AFDC-U family is a recent phenomenon in public welfare programs-in California the program did not begin until February 1964. Prior to that time, intact family units with dependent children in need of public assistance had two options: (1) general assistance, or "rehief," which is dependent on county funds, provides extremely low benefits, and for all practical purposes is unavailable in many localities and difficult to obtain in many others; and (2) separation of husband and wife so that the mother and the children could become eligible for benefits under the AFDC program. ${ }^{12}$ Thus the AFDC-U prograin provides assistance to a portion of the "able-bodied poor," one of the groups for which society traditionally has been most reluctant to provide stable financial assistance-partly out of fear that to do so would undermine their incentive to seek gainful employment. ${ }^{13}$

\section{II}

\section{THE VIEW FROM BELOW}

\section{A. On the Edge of Disaster: Becoming a Welfare Recipient}

The typical AFDC-U recipient-father, ${ }^{14}$, when he appears with his wife at the welfare agency to apply for aid, has only about ten dollars left in his pocket, has been out of work for three weeks or more, and has three or four children (five or six if he is Mexican-American) to feed and care for. He is comparatively young (thirty to thirty-five), and when he last worked was earning less than four hundred dollars per month in a job requiring few skills. His wife is not employed, and for a while they got by on unemployment compensation or with the help of small loans and gifts from friends and relatives, but these resources are exhausted. Moreover, given his usual income, he is deeply in debt (thirty-nine percent have debts in excess of one thousand dollars) and is worried about how he will meet his monthly payments as well as feed, clothe, and house his family.

He is not a stranger to this city. Chances are that he has lived in this community for ten years or more-though he moved to his present ad-

12 Cal. Stats. 1955, ch. 1956, $\S 1$, at 3586.

13 Part of the political support for the AFDC-U program in California came from groups that hoped this program would: (1) curb "immorality" among AFDC recipients, and (2) remove an incentive for the unemployed father to desert his family.

14 It slould be emphasized that the composite picture of the recipient presented in this paper is limited to the sample interviewed in this study. No wider generality can be claimed at this stage in the research. Consequently, whenever a finding is reported about "recipients" the qualifying plrase "in this sample" is implied. 
dress less than two years ago-and he has lived in the state over fifteen years. He has not apphed for welfare aid before (sixty per cent in this sample had not), and he was reluctant to do so. But his friends and relatives, and finally his wife, have urged him to go to the welfare department, and eventually he agreed.

When applicants arrive at the welfare department-or Social Service Department as it is called in this county-they first meet the receptiomist. She asks them some factual questions (for example, "What is your name?" "Where do you live?" "Have you ever applied for aid here before?") and then directs them to the waiting room. In this roomlight, windowless, but reasonably pleasant-an apphicant may begin to experience the sense of estrangement evident in the responses of most recipients interviewed. As one father described it, "I looked around [the waiting room] and saw a bunch of old people and Negroes-I felt I should be someplace else."

But few recipients were this sensitive and perceptive about their personal reactions to the experience of becoming and being a welfare recipient. For most, this sense of estrangement is expressed in a less subtle way: Our respondents almost never (and most respondents never) referred to welfare recipients as "we" but as "they." This characteristic estrangement-also manifest in a tendency to view oneself as an atypical recipient, a self-conception which seemed to be held by nearly all the recipients interviewed ${ }^{15}$ - reflects the desire of these recipients to dissociate themselves from the image they have of other recipients. Our respondents expressed opinions about other public welfare recipients which usually have been associated primarily with conservative, anti-welfare groups. For example, fifty-eight per cent of the recipients interviewed beheve that more than twenty-five per cent of all welfare recipients remam on welfare longer than necessary, and nearly one-half believe that over twenty-five per cent of all recipients "cheat" the welfare department."

In addition, the recipients seemed to use their own situations as a standard for evaluating the claims of other recipients. For example, each recipient regarded as justifiable his own reason for seeking welfare

15 Few clear exceptions to this generalization were found. One was a woman in a small group of persons (not included in the data reported in this paper) whose applications for aid were denied. This woman had previously been a welfare recipient and had re-applied for aid. Subsequent to denial of her re-application, she became a conımunity organizer in an OEO project. When interviewed, she spoke of welfare recipients as "we."

10 A report of a fifteen-month survey of welfare fraud conducted by the California State Department of Social Welfare and released in December 1965 found that established fraud amounted to a "fraction of $1 / 30$ th of 1 per cent of the total Aid to Families of Dependent Children caseload." California State Dep't of Social Welfare, News Release, Dec. 10, 1965. 
assistance, but often judged other reasons depending on their similarity to his own situation. Thus in response to specific questions asking whether a person would be justified in requesting assistance under various specified conditions, Mexican-American recipients (a number of whom were farm laborers) were more hkely to say that a farm laborer is justified in requesting aid during the off-season than were Negro and Caucasian recipients. Negro and Caucasian recipients were more likely to say that recipients should not be expected to take farm labor jobs than were Mexican-American recipients. And the Mexican-American and Negro recipients were much more apt than were Caucasians to say that a man is justified in requesting welfare assistance if he cannot find work because of discrimination.

\section{B. Welfare Assistance: A Right or Charity?}

Returning to the typical (or, more accurately, composite) recipient couple that we followed into the waiting room of the welfare office, after a wait of from one-half to two hours ${ }^{17}$ a lady (the intake social worker) appears, takes them into an office in the inner recesses of the building, and begins the application interview. What are the recipients' expectations of this situation? What are their conceptions of the request they are making?

Welfare àssistance under federally assisted programs such as AFDC-U is a right in that entitlement is defined by statute and not by the arbitrary (however well-motivated) decision of a charitable organization. If a family meets the statutory requirements the agency is obligated to grant their clain for assistance. ${ }^{18}$

While this conception of the federal assistance programs is held by the soical workers in the department studied, our findings suggest that few recipients regard welfare assistance as a right. One indicator, though a rather marginal one, is that none of the recipients interviewed could define "AFDC-U." Thirteen per cent gave a partially correct definition (for example, "Aid to Families of Dependent Children-Universal"), but seventy-eight per cent said they had no idea what the term meant. ${ }^{10}$

17 It must be emphasized that throughout this section, we are attempting to present experiences as they were perceived by the recipients. Actually, in the agency studied, applicants rarely have to wait more than thirty to forty-five minutes to see the intake social worker.

18 See generally Reich, The New Property, 73 YaLE L.J. 733 (1964); Taylor, The Nature of the Right to Public Assistance, 36 SocLal Service Rev. 265 (1962).

10 Another indicator of this sort is the difficulty we encountered, in the pre-test stage of this study, in wording questions asking whether a person in certain specified situations is entitled by law to receive aid. This concept of entitlement proved to be exceedingly elusive for recipients. After trying various wordings, we finally settled for "Is he [the person in the specified situation] legally entitled to aid?" It still was necessary, however, to explain the 
A better, more direct indicator is the manner in which the recipients refer to the aid and whose property it is. The statement of one recipient defending the social worker's close scrutiny of recipients' lives characterizes the attitudes of most recipients: "You are going to them for money . . . they are supporting you." A more convincing piece of evidence, because it is quantifiable and less anecdotal, is the recipients' perceptions of who has control over the assistance grant once it is given. Asked whether the social worker has a right to know how the aid money is spent, sixty-six per cent said yes. (Responses of two recipients typify this view: "The social worker's job is to find out that the money is being spent right," and, "They [the social workers] are supposed to know all about a person on welfare.") Asked what the agency would do if the social worker found that aid funds were not being spent properly, seventy per cent of the recipients said that aid would be terminated. And asked whether in their opinion aid should be cut off under these circumstances, seventy-six per cent of the recipients said yes. In the eyes of these recipients, "the new property"-Reich's term for the property to which people are entitled by virtue of government benefits ${ }^{20}$-belongs to the welfare agency.

Thus the stance these recipients adopt toward the welfare agency is not that of a rights-bearing citizen claiming benefits to which he is entitled by law but that of a suppliant seeking, in the words of a number of recipients, "a httle help to tide us over until we can get back on our feet again." Moreover, the "hittle help" they sought was modest indeed. Of those recipients who were able to specify the amount of aid they expected when they applied for assistance, sixty-four per cent said they expected to receive less than one hundred dollars. Since over fifty per cent of the recipients actually were given aid in excess of one hundred dollars, it is not surprising that most recipients were satisfied with the amount they received and that only seventeen per cent reported that the amount of aid granted was less than they had expected.

\section{Agency Decision-Making}

For most recipients, decision-making in the welfare department is a mysterious process, one which they do not understand and one which-as they conceive of it-is not visible to them. According to their descriptions of the apphication interview, the worker asked a great many questions, many designed to find out if they were telling the truth: "They have to check on what you say, so they have to ask all these questions. They

meaning of this question to many recipients, and it was not always clear that recipients were able to distinguish between what the person was legally entitled to receive and what the agency would in fact "give" him.

20 Reich, supra note 18. 
can't just give money to anybody who walks in and says they need it, or they would be in trouble. If she'd given it on my word, she'd been a fool."

In the application interview, the social worker also begins the complicated task of calculating the "budget," a crucial step in the determination of need and of the amount of aid, if any, to which the applicant is entitled. This process is difficult for the staff to master and harder still to interpret to applicants. ${ }^{21}$ In the words of one recipient: The intake worker "sat there and figured and figured a whole bunch of things. All the time she was figuring, I wasn't paying any attention." "Why weren't you paying attention?" "Because I felt uncomfortable being there."

The next stage in the apphication process is deciding whether the recipient is eligible for aid. Actually, this stage-within the agencyinvolves a number of steps and may follow one of several different pathways, but these complexities need not concern us here. As the recipients perceived it, $a$ decision was made-yes or no. The recipients were asked who made the decision; their responses are presented in Table I.

TABLE I

The Locus of Am Decisions as Perceived by Recipients

\begin{tabular}{lcc}
\hline & Number & Per Cent \\
\hline Social worker and someone else & 48 & 52 \\
Social worker, on his own & 27 & 29 \\
Other & 7 & 8 \\
Don't know & 10 & 11 \\
$\quad$ Totals & $\frac{92}{100}$ \\
\hline
\end{tabular}

Table I indicates that recipients divide into two major groups in their responses. The larger group believes that someone other than the worker is involved in the decision to grant aid: "The social worker just helps you fill out the papers-how much family you have, and so on. Then she gives the forms to her boss who says yes or no whether you can get aid." The second group attributes to the social worker the authority to make this decision: "The worker has the right to decide if there is need for aid."

Regardless of the recipient's belief about who malses the decision, it may be of little significance insofar as his view of the legal status of his request for aid is concerned. Compare, for example, the following two statements, representing the two groups of recipients:

\footnotetext{
21 As part of this research, we observed a number of application interviews. Although the research observers were trained, experienced social workers, even they found the budgeting process difficult to follow at points. To fully understand the steps involved, the recipient liad to be able first to understand interpretations by the worker which might include technical terms such as "participation maximum" and second to comprehend anomalies such as the discrepancy between the amount the worker has calculated and has told the applicant is lis minimum need and the lesser amount the agency will grant him.
} 
Worker, on his own:

The worker decided herself. She is very experienced and knows from experience how much a family needs. She is smart and all out to help the needy.

Worker and someone else:

There is someone she [the social worker] has to confer with, a committee or something that agrees. Well, they're the ones-I guess they vote on it or something like that and they say who gets it and who don't.

In either event, the decision is one over which the recipients appear to feel they have-or apparently even expect to have-little control.

In view of these and other findings presented earlier, it is hardly surprising that forty-six per cent of the recipients report that they were not told about their rights on welfare and that sixty per cent said they were not informed about the right to appeal. The point is not whether they were told about these rights-our observations indicate that many, if not most, of these recipients probably were given this information by the social worker-but rather that this information probably is not particularly meaningful and useful to a person who sees himself as a suppliant, and therefore it may be ignored or soon forgotten. An example of their lack of a clear conception of the appeal procedure is seen in the recipients' responses to a question asking to whom a recipient should appeal if he disagrees with a decision made about his case by the welfare department. ${ }^{22}$ These responses are presented in Table II. As the data in this

TABLE II

RecipIents' Perceptrons of the Person to Whom an Appeat Shoutd Be Made

\begin{tabular}{lcc}
\hline & Number & Per Cent \\
\hline Don't know & 28 & 30 \\
"Person in Sacramento" & 15 & 16 \\
"Head of the Welfare Department" & 13 & 14 \\
Social worker's supervisor & 8 & 10 \\
"Person in -" (city in which the central & 7 & 7 \\
administrative offices for the county wel- & \\
fare department are located) & 6 & 7 \\
Social worker & 4 & 4 \\
District attorney & 11 & 12 \\
Other & $\frac{92}{12}$ & $\frac{100}{12}$ \\
\hline
\end{tabular}

table indicate, nearly one-third of the recipients did not know where to appeal, the remainder lacked a consistent conception about where to

22 Actually, imitiation of the appeal procedure is relatively simple for the recipient. He simply writes or calls a field office of the State Department of Social Welfare. And as noted in the text, most, if not all, recipients are told that such a procedure is available and also are given a brochure which includes information about the opportumity to appeal. 
initiate an appeal, and very few considered appealing to a resource outside the welfare system. The "other" category, which includes a variety of responses (for example, "State Personnel Board"), does include a few recipients who said they would see an attorney; but as one of these respondents said, "I'd go to a lawyer, though I don't know what he could do."

\section{The Welfare Department-A Benevolent Autocracy}

The recipients' vague, diffuse, and limited conceptions of their own riglits and of the welfare department's obligations to them contrast sharply with the well-crystallized views most of them have of the welfare agency's rights and of their own obligations to the agency. Some evidence to this point is presented earlier, namely the findings showing that most respondents believe that social workers have a right to know how recipients spend the aid money and, further, that aid would and should be terminated if not spent properly.

The agency, however, also is seen as liaving legitimate authority over recipients extending considerably beyond the surveillance of aid expenditures. This can be illustrated first by further examination of the agency's authority over the management of money. We asked a series of questions on this subject, including a set addressed to the following situation: "Suppose the social worker suggests that a couple on welfare come in once a week for budget counseling." The questions and the responses obtained are given in Table III.

TABLE III

RecipIEnts' OpInions About Bunget Counseling

\begin{tabular}{|c|c|c|c|c|c|}
\hline $\begin{array}{l}\text { Suppose the social worker } \\
\text { suggests that a couple on } \\
\text { welfare come in once a week } \\
\text { for budget counseling: }\end{array}$ & Yes & $\begin{array}{l}\text { No } \\
\text { No. } \%\end{array}$ & $\begin{array}{l}\text { Don't } \\
\text { Know } \\
\text { No. \% }\end{array}$ & $\begin{array}{l}\text { Other } \\
\text { No. \% }\end{array}$ & $\begin{array}{l}\text { Totals } \\
\text { No. \% }\end{array}$ \\
\hline $\begin{array}{l}\text { 1. Would they have to } \\
\text { come in? }\end{array}$ & $57(61)$ & $24(27)$ & $11(12)$ & -- & $92(100)$ \\
\hline $\begin{array}{l}\text { 2. Would their aid be } \\
\text { cut off if they re- } \\
\text { fused to come in? } \\
\text { 3. Should the conple } \\
\text { be expected to come } \\
\text { in? }\end{array}$ & $55(60)$ & $22(24)$ & $14(15)$ & $1(1)$ & $92(100)$ \\
\hline
\end{tabular}

As Table III indicates, not only did most recipients believe that the agency could make budget counseling a compulsory condition for receiving aid, they were virtually unanimous in their belief that couples should be expected to come in if the worker suggests such counseling.

Similar sets of questions were asked about areas of agency authority less directly related to management of the aid grant. For example, if the 
social worker suggests that a recipient see a psychiatrist, seventy-six per cent of the respondents said that the recipient should be expected to go and sixty-six per cent said he must go in order to continue receiving aid. But the recipients perceived some limits to the range of the welfare agency's authority. While sixty-seven per cent of the recipients said that a recipient should go if the social worker suggests marital counseling, only twenty per cent believed that a recipient's aid would be cut off if le refused to follow this suggestion.

However, the findings which most dramatically indicate the extent of authority these recipients confer on the agency and which best illuminate their reasons for granting the agency extensive authority over their lives are those obtained in response to a series of questions about the use of night visits as a means of checking on recipients. ${ }^{23}$ These questions and the recipients' responses to them are shown in Table IV.

TABLE IV

Recrpients' Opinions About Night Searches by the Welfare Departarent

\begin{tabular}{|c|c|c|c|c|c|}
\hline & $\begin{array}{c}\text { Yes } \\
\text { No. \% }\end{array}$ & $\begin{array}{c}\text { No } \\
\text { No. \% }\end{array}$ & $\begin{array}{l}\text { Don't } \\
\text { Know } \\
\text { No.\% }\end{array}$ & $\begin{array}{l}\text { Other } \\
\text { No. } \%\end{array}$ & $\begin{array}{l}\text { Totals } \\
\text { No. \% }\end{array}$ \\
\hline $\begin{array}{l}\text { 1. Should the welfare } \\
\text { department make } \\
\text { night visits? }\end{array}$ & $63(69)$ & $24(26)$ & $3(3)$ & $2(2)$ & $92(100)$ \\
\hline $\begin{array}{l}\text { 2. Does the recipient } \\
\text { have a right to } \\
\text { refuse to let the } \\
\text { worker come into } \\
\text { his home at night? }\end{array}$ & $46(50)$ & $40(43)$ & $5(5)$ & $1(1)$ & $92 \quad(100)$ \\
\hline $\begin{array}{l}\text { 3. Are there any other } \\
\text { times when the re- } \\
\text { cipient has a right } \\
\text { to refuse to let the } \\
\text { worker enter his } \\
\text { home? }\end{array}$ & $34(37)$ & $49(53)$ & $6(7)$ & $3(3)$ & $92(100)$ \\
\hline $\begin{array}{l}\text { 4. Is there a law that } \\
\text { says you can refuse } \\
\text { entry to your home } \\
\text { to anyone who does } \\
\text { not have a search } \\
\text { warrant? }\end{array}$ & $53(87)$ & $5(8)$ & $3(5)$ & -- & $6 \mathrm{I}^{\mathrm{a}}(100)$ \\
\hline $\begin{array}{l}\text { 5. (If yes to \#4) } \\
\text { Does this law ap- } \\
\text { ply to welfare re- } \\
\text { cipients? }\end{array}$ & $35(66)$ & $9(17)$ & $9(17)$ & -- & $53^{a}(100)$ \\
\hline
\end{tabular}

a These two questions were added to the schedule after the first 31 interviews had been completed.

23 For a penetrating analysis of the legal aspects and constitutionality of this practice see Reich, Midnight Welfare Searches and the Social Security Act, 72 YALE L.J. 1347 (1963). 
As the data presented in Table IV indicate, over two-thirds of the recipients favor night searches by the welfare department. The reasons the recipients gave for favoring this practice are anticipated by findings reported earher: (1) The agency has a right to know how aid funds are spent; and (2) many recipients cheat or continue to accept aid after they no longer need it.

However, the data of greater interest in this table concern the recipients' views about a recipient's right to refuse entry to the social worker at night. Nearly ninety per cent of the respondents say that there are laws which give a person the right to refuse entry to anyone who does not have a search warrant, and over two-thirds believe that these laws apply to welfare recipients. Yet only one-half the respondents say that a welfare recipient has a right to refuse entry to the social worker on a night visit. How can the seening inconsistency in these findings be explained? Why (as further analysis of these data not reported here reveal) do a substantial proportion of the recipients who say that there is a law that permits the recipient to refuse entry to the worker at night also say that the recipient has no right to invoke this law? Analysis of the recipients' responses to these questions reveals a common theme: The recipient has an obligation to let the worker come into his home at any time because the welfare agency is supporting him: "You are going to them for money. They got the right to go and look in your house without no questions-they're supporting you." And this theme appears in the statenients of those recipients who said that the recipient does have a right to refuse entry at night: "According to the criminal law, they [the recipients] do have the right, yes-I don't think it's right, but they do have that right." "All people have the right not to let someone enter their home if they don't want thein to. But in the case of the social worker, one ought to let her in." In other words, most recipients favored the practice of night visits-they tend to differ only over the necessity for the agency to obtain a search warrant.

\section{CONCLUSION}

Before considering the meaning and significance of these findings, the limitations of the research should be noted. The welfare recipients interviewed in this study were drawn from one aid program as administered in one locality. It is not known to what extent these findings hold for recipients of other public assistance programs ${ }^{24}$ or for recipients in other

24 In collaboration with Irving Piliavin, Associate Professor, School of Social Welfare, University of California, Berkeley, the author currently is conducting a study designed to collect data comparable to that reported in this article from samples of recipients in otlicr categorical aid progranss. 
communities in which, among other things, the character of the public welfare agency may be quite different. Nevertheless there is reason to believe that some of the findings may have wide generality.

For one thing, the conservative (in the sense that assistance is perceived as a privilege rather than a riglit) views expressed by these recipients on certain welfare issues are not surprising. The prevalence of political and social conservatism and of submissive attitudes toward authority among persons in low-income groups lias been documented in a number of studies. ${ }^{25}$ Moreover, while social workers and others concerned with promoting the expansion of welfare programs liave long advocated that public assistance should be provided on a basis of entitlement rather than privilege, public welfare recipients have had few opportunities to be exposed to this view.

For these are people with limited education and limited access to the publications and forums in which this view is expressed. Nor are more than a few recipients exposed to orgamizations whicl attempt to inform them of their riglits and of the welfare agency's obligations to them-in fact, few such organizations exist. ${ }^{26}$ In view of these conditions, only if these recipients had expressed a welfare ideology markedly different from the views reported liere would there have been reason to suspect that this group of recipients is atypical. ${ }^{27}$

Secondly, althougli public welfare departments differ greatly in many ways (including the service orientations of the social work staff and the liberality of assistance grants), certain characteristics are common to many of them: the elaborate complexity of determining eligibility and especially of budgeting (including both the determination of need and of the amount of assistance to which the recipient is entitled); the low visibility, for the recipient, of agency decision-making processes and of appeal opportunities and procedures; the comparative powerlessness, from the recipient's viewpoint, of the line social worker - the person with whom he must deal-in the decisions made about his assistance grant; the linkage of financial assistance to other services so that the aid recipient also automatically becomes a client wlo, at least partly at the discretion of the agency, may become the object of other services (for example,

\footnotetext{
25 See, e.g., Bereison \& Stenner, HunaAN Befavior: An Inventory of ScIentIfic FINDINGS 572-73 (1964). F. 197.

${ }^{26}$ See Brager \& Specht, Mobilizing the Poor for Social Action, 1965 Soctar Welfare

27 It should be emphasized that the recipients interviewed were not all of one mind on welfare issues. In this article, we present the dominant and modal responses obtained from the sample studied. The characteristics of those recipients who expressed divergent opinions-for example, the small group who did not favor night visits-will be examined in subsequent reports by the author.
} 
counseling and psychiatric treatment); and review and surveillance of recipient's expenditure of aid funds beyond that necessary to establish eligibility and detect possible fraud.

Our findings suggest that the presence of these cliaracteristics-common to many public welfare agencies-serves to reinforce and thereby perpetuate recipients' conceptions of themselves as suppliants rather than rights-bearing citizens. Moreover, the presence of these characteristics may obliterate the effects on recipients of the distinctive attributes of specific welfare departments. Thus the dimension which has received the most attention in comparative studies of welfare agencies, namely the extent to which staff are committed to a professional versus a bureaucratic service-orientation, ${ }^{28}$ may, in the presence of the other characteristics enumerated above, have little effect on recipients' conceptions of their rights. In a paradoxical way, commitment to a professional orientation by public welfare workers may, when the above characteristics are also present in the agency, reinforce the suppliant role. For the practices of the welfare agency together with the beliefs about public welfare which many recipients hold when they go to the agency appear to evoke a sense of obligation ${ }^{29}$ to the agency; this sense may be accentuated if the agency is benign and the social worker is kind, sympathetic, and understanding.

These considerations suggest that to the extent that one objective of public welfare programs is to help recipients become "responsible citizens"-an aim presumably shared by both proponents and critics of more liberal welfare programs-the public welfare agency must be organized and operated in such a way that it at least does not generate or reinforce attitudes of submissiveness and suppliance on the part of the recipients. More than that, however, these considerations imply that public welfare agencies-because of their strategic position vis-à-vis the poorcould become positive instruments for the inculcation in recipients of a conception of themselves as rights-bearing citizens, with all of the benefits this may have for increasing self-confidence and hope among these people. ${ }^{30}$ To accomphish this would appear to require, at the very least: radical simplification of the eligibility and budgeting processes so that they are comprehensible to recipients with limited education; high visibility of agency decision-making in individual cases to reduce its apparent arbitrariness (from the recipient's viewpoint) and to make accessible to the recipient the information necessary to understand and review

28 See, e.g., BLaU \& Scott, Format. Organizations 60-74 (1962).

29 For an insightful theoretical discussion of the sense of obligation incurred in donordonee relationships, see Gouldner, The Norm of Reciprocity: A Preliminary Statement, 25 AxIERTCAN Soctorogtcax REv. 161 (1960).

${ }^{30}$ See generally Cahn \& Cahn, The War on Poverty: A Civilian Perspective, 73 YarE L.J. 1317 (1964). 
agency decisions affecting his claim; high visibility and accessibility of appeal procedures; and a redefinition of the social worker's role away from that of an instrument of agency rules and regulations towards one of an advocate who, because he is informed and knowledgeable about the applicant's rights and the agency's obligations, can assist the applicant to secure the maximum benefits to which lie is entitled. For as Edgar and Jean Cahn have stated, "Law is made not merely througl statutes and legislative programs, but also through modes of official behavior."31 The mode of official behavior necessary to inculcate in recipients a conception of themselves as rights-bearing citizens is one which provides them with "the means and the effective power wherewith to criticize, to shape, and even to challenge the actions or proposed actions of officials." ${ }^{\prime 32}$ This perspective, if implemented in the public welfare agency, has the potential of becoming the agency's most effective means of enhancing the dignity and self-respect of the persons it seeks to serve.

32 Id. at 1330 . 